\title{
INFORMACIJA
}

\section{POLITINĖS KOMUNIKACIJOS PRAKTINÉ PROBLEMATIKA: PREZIDENTĖS D. GRYBAUSKAITĖS RETORIKOS YPATUMAI}

\author{
ANDRIUS ŠUMINAS
}

Vilniaus universiteto Komunikacijos fakultetas, doktorantas Vilnius University Faculty of Communication, Ph. D. Candidate Sauletekio al. 9, 10222 Vilnius

El.paštas andrius.suminas@gmail.com

Aurelija Vernickaité

Vilniaus universiteto Komunikacijos fakultetas, doktorantè Vilnius University Faculty of Communication, Ph. D. Candidate Sauletekio al. 9, 10222 Vilnius

El.paštas aurelija.vernickaite@kf.stud.vu.lt

„Koks yra retorikos tikslas? Jos tikslas - ịtikinèjimas, kitų protų kontrolè per asmeninę ịtaką ir galią. Kur mūsų galimybès tolimesnèje karjeroje?

Bare, sakykloje, ant kelmo, Senate, universitete.“

Vudrovas Vilsonas (Woodrow Wilson)

Straipsnyje apžvelgiamas vienas iš įdomių ir probleminių Lietuvos politinès retorikos atveju - Respublikos Prezidentès Dalios Grybauskaitės retorikos ypatumai. Politinès retorikos menas nagrinèja- 
mas šimtmečius, bet Lietuvos politinès retorikos tradicija turi dar pernelyg silpną mokslo tiriamąji pamatą.

Vilniaus universiteto Komunikacijos fakulteto Politinès komunikacijos klubas ${ }^{1}$, turèdamas tikslą gilinti šiuos tyrimus, nagrinèti politinès kultūros tendencijas Lietuvoje, surengè diskusiją „Prezidentès D. Grybauskaitès politinè komunikacija ir retorika“, kurios metu savo įžvalgomis ir pastebejimais dalijosi retorikos tyrinètojai, politikos apžvalgininkai ir akademinès bendruomenès nariai. Tikètina, kad artimiausiu metu atsiras ir mokslinių darbų, kuriuose bus tyrinejjamas Prezidentès D. Grybauskaitès kalbejjimas ir politinè retorika.

Reikšminiai žodžiai: politinè retorika; lyderio retorika.

Nors Lietuvoje retorika yra tyrinèjama ne vieną dešimtmetị (Regina Koženiauskienè, Irena Buckley), tačiau politinès retorikos tyrimų tradicija dar tik formuojasi. Lietuvos mokslinèje literatūroje randame kelių autorių darbų, kurie skirtingais aspektais susiję su politine retorika (R. Koženiauskienė, Laura Butkutė, Lauras Bielinis). R. Koženiauskienè tyrinèjo Lietuvos parlamentarų retoriką etiniu požiūriu. Autorè daro išvadą, kad „Lietuvoje pastaruoju metu padaugejo atvejų, kai politikų kalbos turinys labiau primena užstalès kalbas uždarame verslininkų bičiulių ratelyje, nei profesionalias kalbas ịstatymų leidimo ir svarbiausioje tautos atstovavimo institucijoje“.2 Autore taip pat yra palyginusi XVI a. politiko Andriaus Volano ir atkurtos Lietuvos Seimo Pirmininko Artūro Paulausko politinę retoriką. ${ }^{3}$ L. Bieli-

Politinès komunikacijos klubas vienija akademinès bendruomenès narius, siekiančius pagilinti žinias, praktinius igūdžius ir analitinius gebejjimus politinès komunikacijos srityje, nagrinèti mokslinių tyrimų vertą aktualią politikos problematiką.

2 Koženiauskienè, R. Politinė retorika etiniu požiūriu. Parlamento studijos. 2005, Nr. 3, p. 110-121.

3 Koženiauskienè, R. Brandaus Lietuvos piliečio paieškos politikų kalbose. Parlamento studijos. 2006, Nr. 6, p. 153-166. 
nis politinę komunikaciją ir retoriką tyrinejjo iš lingvistinių pozicijų. ${ }^{4}$ Pasak L. Bielinio, politinè komunikacija funkcionuoja kaip kalbinè tikslų ir ketinimų sistema, paremta strategijomis, atliekančiomis tris funkcijas: instrumentinę-padeda kontroliuoti klausytojo dèmesị, struktūruoti adresato gaunamą informaciją; pateisinimo - remiantis ja aiškinamos kalboje esančių teiginių ir argumentų atsiradimo priežastys; saviprezentacijos - skirta norimam politiko įvaizdžiui sutvirtinti, o „politinis tekstas yra komunikacinė priemoné, kurioje didelę reikšmę turi tekstą/kalbą egzistuojantys veiksniai, skirti paveikti adresato (skaitytojo/klausytojo) veiksmus, vertinimus ir situacijos supratimą". L. Butkutė nagrinèjo frazeologizmų stilistines ir retorines išgales politiniame diskurse. ${ }^{5}$

Per paskutinius 20 metų Lietuvos valstybès vadovų - Aukščiausiosios Tarybos - Atkuriamojo Seimo Pirmininko Vytauto Landsbergio (1990-1992), Prezidento Algirdo Mykolo Brazausko (1993-1998), Prezidento Valdo Adamkaus (1998-2003 ir 2004-2009) ir Prezidento Rolando Pakso (2003-2004) - bendravimo stilius būdavo aptarinejjamas publicistikoje, rečiau - mokslo darbuose. Prie svarbiausių darbų būtų galima priskirti L. Bielinio atliktą kalbejjimo strategijų analizę politiniame tekste, remiantis Prezidento A. M. Brazausko kalbų pavyzdžiu. ${ }^{6}$ Dar mažiau šiuo lyderio retorikos aspektu yra nagrinėti pirmosios Respublikos vadovai. Šios aplinkybès paskatino aktualią naujo Lietuvos vadovo politinès komunikacijos problemą, iškeltą viešojoje erdvejje, imti nagrinèti praktiniu ir teoriniu lygiais.

4 Bielinis, L. Lingvistiniai politinès komunikacijos supratimo aspektai. Respectus Philologicus. 2002, Nr. 2.

5 Butkutè, L. Frazeologizmų stilistinès ir retorinès išgalès politiniame diskurse. Lituanistica. 2008, Nr. 2, p. 44-54 ir Butkutè, L. Frazeologinių junginių stilistinè raiška Seimo stenogramose. Parlamento studijos. 2009, Nr. 8, p. 169-178.

6 Bielinis, L. Kalbèjimo strategijos politiniame tekste (Lietuvos Respublikos Prezidento A. Brazausko kalbų pavyzdžiu). Socialiniu mokslu daktaro disertacija. Vilniaus universitetas, 1996, p. 124. 


\section{Prezidento-lyderio retorika}

Plačiąja prasme retorika ${ }^{7}$ yra vadinamas įtikinejjimo menas. Itikinéjimo konceptu rèmèsi senovès graikų mokslininkai-Aristotelis, Platonas. Veikale „Retorika“ Aristotelis teigia, jog kalbejjimas yra geriausias ir garbingiausias būdas apsiginti. Taigi pabrèžiamas ne siekis nugalèti, įsitvirtinti, bet garbingas dialogas, įtikinimas argumentais. Gerardas Hauseris retoriką apibrèžia kaip „simbolių valdymą siekiant koordinuoti socialinius veiksmus“. Kiti retoriką sieja su idejjų, vertybių, nuomonių ir ísitikinimų komunikacija. ${ }^{8}$

Kennethas Burke'as aiškina, kad politine retorika siekiama manipuliuoti žmonių issitikinimais, o pagrindinè politinès retorikos funkcija - žodžiais formuoti pažiūras arba paveikti žmogaus veiksmus. Politiniais pasisakymais siekiama konkretaus tikslo ir stengiamasi vienaip ar kitaip paveikti auditoriją. ${ }^{9}$ Be to, kaip teigia L. Bielinis, komunikavimas politikoje, žiūrint i jị instrumentiškai, netenka neutralumo ir igyja ne paprastos komunikacijos reikšmę, kai kalbantysis bando perteikti tam tikrą informaciją klausančiajam, bet konkrečios valios ir valdžios realizavimo reikšmę. ${ }^{10}$

R. Koženiauskienė politines kalbas skirsto ị diplomatinę, agitacinę, mitinginę, karinę patriotinę ir išskiria tris pagrindines viešųjų kalbų funkcijas: informacinę, apeliacinę ir estetinę. Politinių lyderių viešosiose kalbose galima įžvelgti visas tris funkcijas, tačiau labiausiai išryškejja apeliacinè funkcija. Apeliuoti, tai reiškia stengtis paveikti klausytoją. Apeliacinę funkciją R. Koženiauskienè dar vadina impresine, nes ji

7 Retorikos terminas kilęs iš graikų kalbos žodžio rhetor, kuris reiškia viešai susirinkimuose kalbanti žmogų.

8 Atwater, D. Senator Barack Obama: The Rhetoric of Hope and the American Dream. Journal of Black Studies. 2007, vol. 38, p. 121-129. Prieiga per internetą: <http://jbs. sagepub.com/cgi/content/abstract/38/2/121> [žiūrèta $2010 \mathrm{~m}$. balandžio 19 d.].

9 Burke K. A Rhetoric of Motives. Berkeley: University of California Press, 1969, p. 343. Prieiga per internetą: <http://books.google.lt/books $>$ [žiūrèta $2010 \mathrm{~m}$. balandžio $31 \mathrm{~d}$.].

${ }^{10}$ Bielinis, L. Lingvistiniai politinès komunikacijos supratimo aspektai. Respectus Philologicus. 2002, Nr. 2. 
„veikia klausytojų valią, mintis, nuostatas, įsitikinimus bei elgesį; šia funkcija siekiama nugalèti auditoriją“."11

Pasak Lerojaus Dorsey, retoriné lyderystė suvokiama kaip lyderystè = vadovavimas, pasireiškiantis per kalbą ir įtikinejjimą. ${ }^{12}$ Kai kurie mokslininkai mano, kad lyderystè yra nulemta tam tikrų asmenybès fizinių ir mentalinių savybių - atkaklumo, fizi-

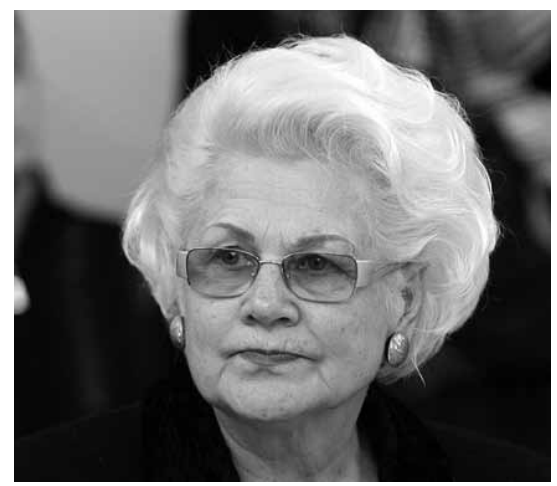

Regina Koženiauskienè: „Prezidentès D. Grybauskaitės retorika yra kario retorika“ nès išvaizdos, socialumo; yra žmonių, tiesiog "gimusių būti lyderiais“. Priešingybė tam - lyderystè, kylanti iš žmogaus užimamų pareigų organizacijoje. Kitų teigimu, lyderiai savo rankose turi galią, kurią suteikia jų šalininkai. Tai vadinamoji charizmatinė lyderystè. Bendrąja prasme lyderystė yra priemoné, per kurią asmuo veikia kitą asmenị ar grupę siekdamas tam tikrų tikslų. Daugelis mokslininkų įtaką sieja su komunikacija. Fairhurst ir Starras teigia, kad lyderystė yra kalbos žaidimas. Taigi lyderystès pagrindas - retorika.

Karnegio technologijos institutas skelbia, kad „kalboje yra dar kažkas, be žodžių, ir šis kažkas turi reikšmę. Ne taip svarbu, ką jūs sakote, o kaip jūs sakote“. Anot Roberto Dentono ir Gario Woodwardo, prezidento statusas siejamas su galia, mitu, legenda ir ịtikimumu. Taigi viskas, ką daro ir sako prezidentas, turi prasmę ir ką nors reiškia, turi itakos. Kiekvienas veiksmas, žodis ar frazė yra suplanuojami ir „apgalvojamas galimas atsakas“. Prezidentinè galia pirmiausia yra įtikinimo

${ }^{11}$ Koženiauskienè, R. Retorika: iškalbos stilistika. Vilnius, 2001, p. 52-53.

12 Dorsey, L. The Presidency and Rhetorical Leadership. College Station: Texas A\&M University Press, 2002, p. 270 p. Prieiga per internetą: < http://books.google.lt/books> [žiūrèta $2010 \mathrm{~m}$. balandžio 19 d.]. 
galia - per kalbą prezidentas vadovauja šaliai ir siekia ịtikinti tautą. ${ }^{13}$ R. Dentonas ir I. Hahnas prezidentystę aiškina kaip retorinę ir ịtikinejjimo instituciją, prezidentinè retorika - tai galia pateisinti, legitimizuoti, ịtikinti, ¡̨kvèpti. Tokiomis politinèmis kalbomis siekiama mobilizuoti visuomenę ir skatinti socialinius veiksmus. ${ }^{14}$

Prezidentineje retorikoje labai svarbi susitapatinimo ideja - prezidentas siekia itikinti tautą, kad jis susitapatina su jos interesais, o tautos interesas yra susitapatinti su prezidentu. ${ }^{15}$

Kaip pastebi J. Cookas, neretai yra spraga tarp to, ko tauta iš prezidento tikisi, ir realių prezidento teisių ir galių, kurias jam suteikia ir riboja Konstitucija. Prezidento buvimas centrine politine figūra reikalauja daugiau galių ir teisių nei jam suteikia Konstitucija. Siekdami užpildyti šią spragą prezidentai pasitelkia retoriką, ịtikinimas tampa galios šaltiniu. Anot J. Cooko, konstitucinès prezidento galios ir retorinẻ lyderystė padeda užtikrinti pusiausvyrą tarp to, ko žmonès tikisi iš šalies vadovo ir ką jis gali. ${ }^{16}$

C. Harto manymu, prezidentai įtaką gali išplèsti tik per kalbẻjimą, ir dažniausiai per ji gauna atsaką iš tautos. ${ }^{17}$ Kerol Gelderman priduria, kad prezidentas, norintis būti ne tik vykdomąja valdžia, bet ir vadovauti tautai, turi būti plepus. Kalbèjimas yra moderniosios prezidentystės pagrindas. ${ }^{18}$

${ }^{13}$ Cheng, M. Constructing a new political spectacle: tactics of Chen Shui-bian's 2000 and 2004 Inaugural Speeches. Discourse Society. 2006, vol. 17(5), p. 583-608. Prieiga per internetą: < http://das.sagepub.com/cgi/content/abstract/17/5/583> [žiūrèta $2010 \mathrm{~m}$. balandžio 19 d.].

${ }^{14}$ Ten pat.

15 Ten pat.

${ }^{16}$ Zarefsky, D. The Presidency Has Always Been a Place for Rhetorical Leadership. The Presidency and Rhetorical Leadership. College Station: Texas A\&M University Press, 2002, p. 270. Prieiga per internetą: <http://books.google.lt/books> [žiūrèta 2010 m. balandžio $19 \mathrm{~d}$.].

${ }^{17}$ Teten, R. "We the People": The "Modern" Rhetorical Popular Address of the Presidents during the Founding Period. Political Research Quarterly. 2007, vol. 60, p. 669-682. Prieiga per internetą: <http://prq.sagepub.com/cgi/content/abstract/60/4/669> [žiūrèta 2010 m. balandžio 19 d.].

${ }^{18}$ Ten pat. 
Giliausios prezidentinès retorikos tyrimo tradicijos susiformavo Jungtinėse Amerikos Valstijose. Tai siejama su tuo, kad XX amžiuje prezidentas tapo svarbiausia politinès retorikos figūra. JAV politikos transformacija lèmè moderniosios prezidentystès, kuri dar kitaip vadinama retorine prezidentyste (angl. rhetorical presidency), atsiradimą. Nuo Teodoro Ruzvelto ir Vudrovo Vilsono prezidentavimo laikų populiarioji, arba masine, retorika tapo pagrindiniu prezidentinio valdymo irankiu. ${ }^{19}$ Prezidentai reguliariai ieškodavo visuomenès paramos savo siūlomiems įstatymams ir kitoms iniciatyvoms. Nekvestionuojama politinès kultūros dalimi tapo tikèjimas, kad prezidentas turi būti populiarus lyderis. Prezidentams tapo iprasta save ginti viešai, reklamuoti politines iniciatyvas visuomenejje, ịkvejpti tautą. ${ }^{20}$

Žinoma, retorinis prezidentavimas JAV atsirado ne tik dèl institucinių pokyčių, tokių kaip Baltụjų rūmų personalo augimas ar besikeičianti Kongreso narių politinè elgsena, - tai yra sudètinga šios šalies politikos raidos pasekmè. Prezidentinè lyderystė yra pateikiama kaip priešnuodis prieš „aklavietę“ JAV pliuralistinejje sistemoje ir vaistai nuo „nevaldymo“. ${ }^{21}$

Šiuolaikiniams prezidentams retorika yra tapusi neatskiriamu jų galią ir lyderystę ịteisinančiu ịrankiu. George'as W. Bushas pasinaudojo retorikos galiomis siekdamas parodyti save kaip moralini tautos atstovą. Kalboje, pasakytoje Kongrese praejus keturiems mėnesiams po 2001 m. rugsèjo 11-osios atakų, Šiaurès Korèją, Iraną ir Iraką jis pavadino „blogio ašimis“, kurios kelia grèsmę „pasaulio taikai“. Per tokią retoriką Bushas iškèlè savo autoritetą, pavaizduodamas prezidentą ne tik kaip amerikiečių, bet ir visos žmonijos amžinųjų moralinių vertybių gynėją. Po šios kalbos, kaip rodo apklausos, 91 proc. amerikiečių manė, kad G. V. Busho politika nukreipta teisinga linkme. Tokia retorika neabejotinai sustiprino jo autoritetą ir valdžią.

${ }_{19}$ Tulis, J. The rethorical presidency. Priceton Univercity Press, 1987, p. 209.

${ }^{20}$ Ten pat.

${ }^{21}$ Ten pat. 
Retorika gali atskleisti ne tik lyderio poziciją, bet ir ją sustiprinti - paversti įtaigesne, nei iš tikrųjų suteikta teisès aktais. Pasigirsta nuomonių, kad Lietuvos Prezidentè D. Grybauskaitė savo veiksmais, taip pat ir politine retorika peržengia jai Lietuvos Respublikos Konstitucijoje apibrèžtas galias ir teises. Kalbant apie Lietuvos konstitucinę sandarą, reikia pažymèti, kad 1998 m. Konstitucinis Teismas yra pažymėjęs, kad Lietuva - parlamentinè respublika su „kai kuriais vadinamosios mišrios (pusiau prezidentinès) valdymo formos ypatumais“. Alvidas Lukošaitis Lietuvos politinę sandarą apibūdino kaip „parlamentinę sistemą su pakankamai dideles galias turinčiu prezidentu“.22

Konstitucija aiškiai apibrèžia Lietuvos prezidento galias, tačiau praktikoje tas galias gali susilpninti arba išplèsti politinė šalies kultūra, dominuojanti ideologija, santykiai su piliečiais. Pasak A. Lukošaičio, politinei kultūrai gali būti būdingas didelis piliečių nepritarimas tokiems demokratiniams institutams kaip politinès partijos bei jų valdymas ir vyrauti pritarimas personifikuotai politikai ir „stipriam“ prezidentui. Arba atvirkščiai. Taigi politinès kultūros „prezidentacijos“ ir „parlamentarizacijos“ tendencijos gali kaitaliotis. ${ }^{23}$

\section{Politinès komunikacijos klubo diskusijos}

Prezidentès D. Grybauskaitès politinè retorika jau nuo inauguracinès kalbos (2009 m. liepos 12 d.) sulaukè didesnio politologų, politikų, apžvalgininkų dėmesio, palyginti su buvusių prezidentų pranešimų sklaidos stiliais ir forma. Štai keletas ištraukų iš Prezidentès D. Grybauskaitès kalbų ir pasisakymų, viešojoje erdvẻje sulaukusių didesnio dèmesio ir vertinimo:

„Kritikuokite valdžią - ir mane, kaip jos dalį, jei to reikia! Bet ne-

${ }^{22}$ Lukošaitis, A. Lietuvos Respublikos prezidento galios ir rinkimu pažadu realizavimo galimybès. Pranešimas, 2003. Prieiga per internetą: <www.tspmi.vu.lt/files/mokslkonfer/ lukosaitis_2003.doc> [žiūrèta 2010 balandžio 19 d.]

${ }^{23}$ Ten pat. 
pamirškite: nuo valdžios kritikos iki valstybès griovimo gali būti tik vienas žingsnis. Tuščia kritika neišspręs nei vienos problemos““.24

„Man reikia Vyriausybès, kuri galvotų apie šalį, kuri darytų tai, ką privalo daryti šioje situacijoje Vyriausybè, ir atsakingai siektų rezultatų. Tai yra dirbtų ir mažiau šneketų. To prašau ir reikalauju iš šitos Vyriausybès“.25

„Dabartiniai ministrai gal ir ne tokie šaunūs, bet bent jau nevagia“. ${ }^{26}$

„Užsienio reikalų ministras ne visuomet girdi, ką sako prezidente, ir aš jam priminiau, kad jis tai turi daryti, nes tai yra mano konstitucinè teisè, ir girdèti prezidentę užsienio reikalų ministrams privaloma“. ${ }^{27}$

Viešoje diskusijoje „Prezidentės D. Grybauskaitės politinė komunikacija ir retorika ${ }^{\text {“28 }}$ pastabų ir įžvalgu pateikè Vilniaus universiteto Filologijos fakulteto profesorè Regina Koženiauskienè, Vilniaus universiteto Tarptautinių santykių ir politikos mokslų instituto docentas Lauras Bielinis, politikos apžvalgininkas ir interneto portalo lrytas.lt vyriausiasis redaktorius Rimvydas Valatka, politikos apžvalgininkas Vladimiras Laučius; rengini stebėdami polemikoje dalyvavo publicistai, akademinès bendruomenès nariai.

\footnotetext{
${ }^{24}$ Lietuvos Respublikos Prezidentès D. Grybauskaitès inauguracijos kalba Seime. Prieiga per internetą: < http://www.president.lt/lt/prezidento_veikla/kalbos/lietuvos_respublikos_prezidentes_dalios_grybauskaites_inauguracijos_kalba_pasakyta_iskilmingame_seimo_posedyje.html>

${ }^{25}$ D. Grybauskaitė: „Man reikia Vyriausybès, kuri dirbtų ir mažiau šnekètų“. BNS. 2010, sausio 18. Prieiga per internetą: <http://www.lrytas.lt/>

${ }^{26}$ Razmaitė, I. Prezidentė: ministrai gal ne tokie šaunūs, bet nors nevagia. Verslo žinios. 2009, liepos 20. Prieiga per internetą: <http://vz.lt/>

${ }^{27}$ D.Grybauskaitè: užsienio reikalų ministras mane ,ne visuomet girdi““. BNS. 2010, sausio 4. Prieiga per internetą: < http://www.diena.lt/naujienos/lietuva/d-grybauskaite-uzsienioreikalu-ministras-mane-ne-visuomet-girdi-256379>

${ }^{28}$ Diskusija surengta Vilniaus universiteto Komunikacijos fakulteto Politinès komunikacijos klube $2010 \mathrm{~m}$. vasario 18 dieną.
} 
R. Valatka, rašydamas komentarus, auditorijos yra pastebimas kaip apskritai aštrus politinès valdžios ir atskirų jos veikejjų kritikas. Tad pabrèždamas retoriką kaip ịtikinèjimo ir žodžio meną, kuriuo politikai kuria savo populiarumą visuomeneje ir ittvirtina savo politinị legitimumą, R. Valatka pažymèjo, jog politikas, siekdamas populiarumo, nebūtinai turi

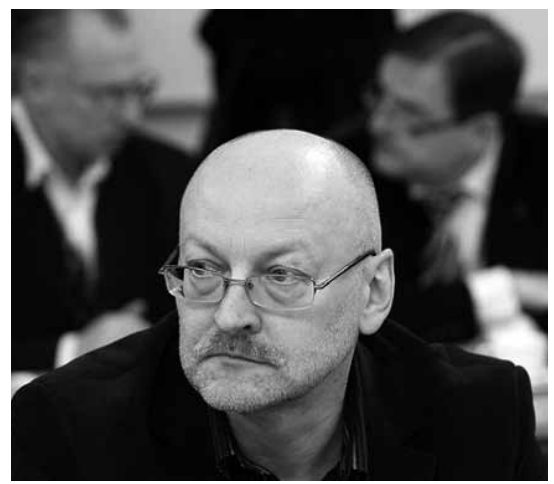

Rimvydas Valatka: „Svarbiausia yra net ne ką pasakyti, bet - kaip tai pasakyti“

kalbèti tiesą, svarbiausia esą „yra net ne ką pasakyti, bet - kaip tai pasakyti“"29.

Kalbėdamas apie politinę retoriką Lietuvos viešojoje erdvejje V. Laučius išskyrè tris pagrindinius politinès retorikos šaltinius. Pirmiausia - tai politinè visuomenė, kurią sudaro rinkejjai ir politikai. Kitas politinès retorikos šaltinis yra oligarchai, kurie savo politinę galią skleidžia ne patys tiesiogiai, bet per savo valdomas žiniasklaidos priemones. Trečiasis politinès retorikos šaltinis - valstybės tarnybos atstovai, apimantys administracinị elitą, diplomatinę valdžią, specialiąsias tarnybas ir kt. Šie politinès galios atstovai viešojoje erdveje paprastai labai nesireiškia ir juos girdime rečiausiai.

Vertindamas D. Grybauskaitės retoriką V. Laučius teigè, jog Prezidentè, kaip ir visas politinès galios šaltinis, „kalba tai, ką nori išgirsti žmonès “30. Prelegentas siūlè atkreipti dèmesị, kad D. Grybauskaitę išrinkę žmonès nori girdèti griežtus ir dažnai gana agresyviai pasakomus teiginius bei pasisakymus, kurie kartais primena Rusijos vadovų reto-

29 Šaltinis: Prezidentès D. Grybauskaitès politinė komunikacija ir retorika. Politinès komunikacijos klubo diskusija. 2010-02-18. Vilniaus universiteto Komunikacijos fakulteto audioarchyvas (irašas).

${ }^{30}$ Ten pat. 
rikos stilių. Šiai nuomonei pritarè ir R. Valatka, teigdamas, jog Prezidentę išrinkę žmonès būtų jos nesupratę, jeigu D. Grybauskaitè būtų prabilusi tokiu pačiu stiliumi kaip buvęs Prezidentas Valdas Adamkus.

Prof. R. Koženiauskienè atkreipė dėmesį, jog „Prezidentès D. Grybauskaitès retorika yra kario retorika“. ${ }^{31}$ Pasak jos, apie tai galima spręsti iš vartojamų gramatinių formų, leksikos, gana ịsakmių pirmojo asmens formų. Tokia retorika „visiškai atitinka Prezidentès charakterị ir rinkimų metu dalytus pažadus“, kuriuose buvo sakoma „kovosiu“. Pašnekovès teigimu, šalies vadovè tarsi stengiasi ịvykdyti rinkejjams duotus pažadus, o su tokia kario retorika puikiai siejasi D. Grybauskaitei būdingas kalbos lakoniškumas ir glaustumas.

VU Tarptautinių santykių ir politikos mokslų instituto docentas L. Bielinis sutiko, kad kario retorika demokratinejje visuomenejje tam tikrose situacijose yra neišvengiama, pavyzdžiui, kai valstybėms kyla pavojus ir šalies vadovas privalo elgtis ir kalbèti kaip karys. Tačiau kario retorika esą „yra logiška retorika, kurioje visuomet išreikštas aiškus tikslas, siekis, numatomas rezultatas“32. Šių dalykų D. Grybauskaitès retorikoje prelegentas teigè labiausiai pasigendąs, nes joje, anot L. Bielinio, pagrindinis akcentas - ne siekiamam tikslui pranešti, bet grasinimui, pavojaus sukèlimui, ịtampos formavimui ten, kur jos visai nereikètų formuoti: „kadangi Prezidentè turi gerą tribūną ir politinę poziciją, tokia retorika leidžia sukurti didžiuli dėmesio intensyvumą, pranešimams suteikti papildomų reikšmių, skirtingų interpretacijų“. Šiuo atveju klausydamiesi politologo vertinimų jau galime palyginti su Dentono ir Woodwardo paminètu teoriniu apibendrinimu, kad esą "galimas atsakas" í veiksmą ir žodị visada apgalvojamas.

Tuo tarpu R. Valatka pažymèjo, kad taikos sąlygomis labai sudètinga vertinti demokratiškai išrinktą politiką per kario retoriką. Tačiau šiai nuomonei nepritarè V. Laučius, cituodamas vokiečių teisès ir politikos filosofą Carlą Schmittą, kuris politikos esmę apibrèžè per konf-

${ }^{31}$ Ten pat.

${ }^{32}$ Ten pat. 
liktą. Etikoje yra skirtis tarp to, kas gražu ir negražu, moralejje - tarp to, kas gera ir bloga, o politikoje politiškumo esmę atskleidžia skirtis tarp draugo ir priešo. Remdamasis C. Schmittu V. Laučius teigé, jog D. Grybauskaitès retorika yra politiška, nes yra ịvardijami priešai, apie juos kalbama, jų atžvilgiu elgiamasi kariškai, tačiau tai yra konfliktas ne tarp kariaujančių kariuomenių, o idejų ir pažiūrų kova. Būtent to diskusijos dalyvis labiausiai pasigedo Prezidentès viešojoje erdvejje išsakomoje retorikoje.

Diskusijoje V. Laučius pabrèžė, kad prezidento rinkimų kampanijos metu D. Grybauskaitė pasirinko strategiją neatskleisti savo pažiūrų, nes esą "taip yra didesnè tikimybè nepadaryti klaidų“. Tačiau jau po rinkimų stinga retorikos, leidžiančios suvokti valstybès vadovo politines pažiūras, juo labiau kad Prezidentè nepriklauso jokiai partijai ir jai negalima priskirti vienos ar kitos politinès partijos pasaulèžiūros.

Vertinant D. Grybauskaitès vartojamas retorines priemones, manieras, argumentų pasirinkimą bei psichologinès įtampos modeliavimą kalbejjimo metu, doc. L. Bieliniui susidaro ịspūdis, jog „Prezidentè aplink save yra išsikasusi apkasą ir visur mato pavojus “33. Be to, anot jo, dèl D. Grybauskaitès vartojamų trumpų, tam tikra administracine igudusio žmogaus maniera sakomų tezių, lieka neaišku, ką tiksliai ji nori pasakyti. Prezidentẻ pasako tik kontūrą, erdvę su kontūru, kurią žmonès užpildo savo lūkesčiais.

V. Laučius priminè ne kartą D. Grybauskaitès viešai išsakytą raginimą: „Mažiau kalbų, daugiau darbų“. Anot politikos apžvalgininko, tokios kalbos visiškai netinka politikui, nes politika pirmiausia yra kalbejimas.

Diskusijos dalyviai pateikè galimų Prezidentès retorikos prognozių. Kaip ir kodèl keisis valstybės vadovès retorika? V. Laučius iškèlè prielaidą, kad Prezidentès kalbų retoriką diktuoja ekonominis sunkmetis ir jam praejus D. Grybauskaitès tonas turètų pasikeisti. Be to, ilgainiui Prezidentès kalbose esančią tuštumą turètų užpildyti politinių pažiūrų

${ }^{33}$ Ten pat. 
turinys, iš kurio bus galima vertinti tikrąsias D. Grybauskaitès politines nuostatas.

Prof. R. Koženiauskienè teigè, kad Prezidentès retorika keisis kartu su pokyčiais valstybèje: „Ankstesni prezidentai dažnai buvo kritikuojami už pasyvumą, o D. Grybauskaitė - aktyvi veikèja, nepraleidžianti progos pasisakyti; Prezidentè žadejo: „būsiu aktyvi prezidentë“, tai tokia ji ir yra“.

R. Valatkos manymu, D. Grybauskaitès politinė retorika neturètų kisti - pasikeis tik visuomenès požiūris ì Prezidentę. Prelegentas D. Grybauskaitès politinę retoriką prilygino „teatrui, kuris kol kas yra i̇domus žiūrovams, tai yra - visuomenei“ ${ }^{34} \mathrm{R}$. Valatka atkreipè dèmesị $\mathfrak{i}$ praktinį ryšių su visuomenę aspektą, kai publika ịpranta prie informacijos: „žmonès susigyvena su kiekvienu teatru, o tada pradeda ji vertinti kritiškai“, todèl esą D. Grybauskaitès gerbejjų gretos ilgainiui mažès.

Taigi apžvelgę praktinị politinès retorikos atveji pasaulio teorijos ir politinès kultūros kontekste, galime sukurti keletą esminių apibendrinimų.

\section{Vietoje išvadų - apie teorijos ir praktikos sąlytị}

Politikams retorika yra jų politinio statuso legitimizacijos įrankis, politinę valdžią ir galią įtvirtinantis instrumentas. Šiais laikais politiko įvaizdis, kuris dažniausiai atsiskleidžia per politinę retoriką, dažnai rinkejjams tampa svaresniu argumentu balsuoti už vieną ar kitą kandidatą negu nuosekliai parašytos ir logiškai pagrịstos rinkimų programos. Todèl šiandien politikai tarpusavyje varžosi ne politinemis programomis ar ideologinemis nuostatomis, o savo retorikos stilistika ir kuriamais ịvaizdžiais, kurie dažniausiai ir nulemia žmonių politinius pasirinkimus rinkimų metu.

Naujausiame politinès komunikacijos amžiuje, kuomet politikams svarbiausias tampa gebejimas save pateikti ir parduoti masėms, politi-

${ }^{34}$ Ten pat. 
nès retorikos tyrimai tampa vis labiau aktualūs ir svarbesni. Pastebimas visuomenès ir mokslininkų susidomejjimas šia sritimi teikia vilties, jog artimiausiu metu sulauksime platesnių studijų, išsamiau nagrinėjančių Lietuvos politikų komunikacijos ir retorikos raišką.

Juolab kad pačios politinès retorikos tradicijos mūsų šalyje dar tik formuojasi, ypač kalbant apie šalies vadovų - prezidentų politinio kalbejimo tradiciją, nes šiuo metu pareigas eina tik ketvirtasis po Nepriklausomybės atkūrimo visuotinai žmonių išrinktas šalies vadovas. Kiekvieno iš iki šiol buvusių prezidentų retorika ir kalbejjimo stilius gana žymiai skyrèsi, o kiekvienas iš jų innešè savo dali ł Lietuvos politinės retorikos tradicijos kūrimą, todèl tik nuoseklūs tyrimai gali atskleisti šalies vadovų politinès retorikos raidą ir pokyčius.

\title{
PRACTICAL PROBLEMATICS OF POLITICAL COM- MUNICATION: PECULIARITIES OF THE PRESI- DENT D. GRYBAUSKAITÉ'S RHETORIC
}

\author{
Andrius Šuminas, Aurelija Vernickaité
}

\section{Summary}

Keywords: political rhetoric, rhetoric of a leader.

The article is intended to analyze the practical problems of political communication, to wit the peculiarities and importance of rhetoric used by political leaders. The paper provides a review on the President D. Grybauskaitès rhetoric, itself an interesting and problematic case of Lithuanian political rhetoric. Further, a synopsis of the rhetoric of political leaders and presidents is set out, along with the role of rhetoric per se in the processes of political communication. 